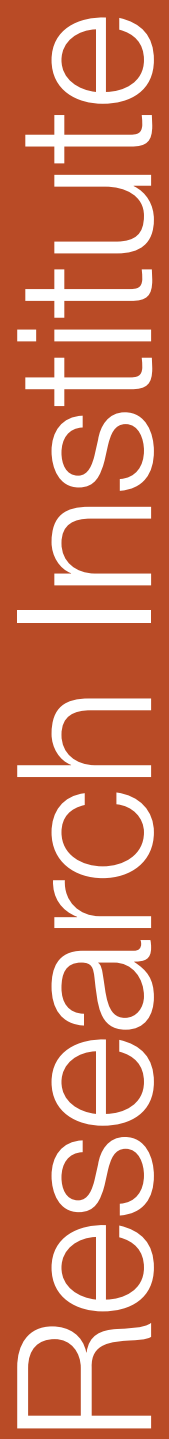

GRI-rapport 2005:9

\title{
The Impossibility of Corporate Ethics
}

- For a Levinasian Approach to Managerial Ethics

Hervé Corvellec and David Bevan

Managing Big Cities 
(C) Gothenburg Research Institute

All rights reserved. No part of this report

may be reproduces without the written

permisson from the publisher.

Gothenburg Research Institute

School of Business, Economics and Law

Göteborg University

Box 600

SE-405 30 Göteborg

Phone: +46 (0) $31-7735413$

Fax: +46 (0)31 - 7735619

e-mail: gri@gri.gu.se

Corresponding author:

H. Corvellec

Box 882, SE-251 08 Helsingborg, Sweden

E-mail: hervé.corvellec@msm.lu.se

ISSN 1400-4801

Layout: Lise-Lotte Olausson 


\begin{abstract}
The moral philosophy of Emmanuel Levinas offers a prospectus of stark impossibility for any programme of business or corporate ethics. It differs from most traditional ethical theories in that for Levinas the ethical develops in a personal meeting of one with the other, rather than residing in some internal deliberation of the moral subject. Levinasian ethics emphasises an infinite personal responsibility arising for each of us in the face of the radical otherness of the Other. It stresses the imperious demand we experience in our humanity to be open to, prepared for and impassioned with that which we may not know, or recognise, about ourselves or about the other. Such a demand transcends our intellectual and/or rational potential, involving us in a carnal and somatic bodily experience of otherness. Consequently, it is questionable whether corporations can even be moral subjects in a Levinasian sense. We assert not only that corporations cannot deal with such a demand, but further that this helps to understand the failure of the business ethics project to date. If we are to speak of Levinasian ethics in any organisational setting, it cannot be a matter of corporate ethics but only a matter of individual managerial ethics. What such an ethics would be like is yet to be outlined and, as a contribution, we propose here a series of questions and injunctions. These questions and injunctions will explicate for individual managers some key terms of a Levinasian practice for which we will propose a vocabulary of otherness, responsibility, proximity, diachrony and justice. This vocabulary will provide managers with insights to an experience of alterity and may encourage them to experience the challenge of radical otherness and the irresistible call to a pre-ontological, timeless and infinite individual ethic.
\end{abstract}

Keywords: Levinas, Managerial Ethics, Responsibility, Justice, Otherness/ alterity

Paper submitted to: Business Ethics, a European Review (Oxford), Campbell Jones (Guest Editor) on December 1, 2005 


\section{Introduction}

In the flat ontology of Emmanuel Levinas, ethics unfolds in our relationship to the other. The author of Totalite et infini (1990b; page 133)(Totality and Infinity (Levinas, 1969) and Autrement qu'être ou au-delà de l'essence (1990a)(Otherwise than Being or Beyond Essence (Levinas, 1991b)) suggests that our potential to open ourselves toward the Other, without any conditionality, is that which determines not only our potential to develop ethical relationships but our capacity to be human. Being ethical - being human - is being open to, (un)prepared for and impassioned by the radical difference of the Other, i.e. that which we do not know already about ourselves or about the other. As human beings, we have a responsibility to be ethical; to achieve this, to be ethical, we must reach toward the being of the other and lurch without compromise into the unknown, and unknowable, which is the infinite and timeless otherness of the Other.

Such a definition of ethics stands in stark contrast to a greater part of the tradition of moral philosophy. For example, instead of situating the production of ethics in some kind of individual deliberation of the moral subject, Levinasian ethics is heteronomous; it situates morality in the relationship that this subject as a being entertains with the beings of other moral subjects. This involves, in particular, that responsibility be originated not in any thematisation - i.e. an attribution of praise or blame for something that can be causally connected and therefore attributed to one's behaviour as knowledgeable and free moral agent - but in the infinite demand and command imposed on one subject by the other. Instead of aiming at providing detailed principle(s), rule(s), code(s) or other form of guidance likely to help anyone to distinguish between good and evil in our actions, Levinas presents us with an ethics that is vague, i.e., emergent, complex and imperious injunctions about what it requires to be human with very few practical directions about how to answer such an injunction. It is therefore legitimate to consider, as a result, whether his ethics is at all possible. On this as well as many other points Levinasian ethics is in a deliberate rupture with the tradition of moral philosophy. And it is an important rupture.

The resounding effect of Levinas's thinking has changed the course of modern thought, Jacques Derrida (1997) observes. Our contention in this article is that the pre-emptive re-direction of moral philosophy proposed by Emmanuel Levinas actually involves a corresponding realignment of business ethics. To substantiate such a contention, we first briefly describe the ethics of Emmanuel Levinas, insisting on the centrality it gives to the carnal and somatic experience of the other. Building on the centrality of this bodily experience, then in a second section we explain why corporations, being deprived of body, can hardly be regarded as moral subjects in a Levinasian sense. The possibility 
of a business or corporate ethics, and of any codification of the ethical, having been dismissed, that which remains is only the possibility of a managerial ethics. We therefore reason in the third and final section about the possibility of a Levinasian managerial ethics and speculate about that which such an ethics could be, formulating our answer in a vocabulary of otherness and responsibility, vulnerability, proximity and justice, and insisting on the endless responsibility for the other it involves for managers. Such an abduction of ethics in business contexts, our concluding point, is of essential importance for management and capitalism if these are not to be regarded, some day in the future, as another avatar of modern barbarity.

\section{The Ethics of Emmanuel Levinas}

Approaching ethics from the perspective of Emmanuel Levinas involves approaching philosophy as ethics. As Philippe Nemo states (Levinas, 1985, 1992), Levinas' main thesis is that ethics is first philosophy, starting from which the other branches of metaphysics take their meaning; "a relation with the other that cannot be reduced to comprehension" (Critchley, 2004; page 12), an encounter which cannot be conceptualised (Derrida, 2001). It is complex if not impossible to explain (Lyotard, 1986; Peperzak, 1997), and difficult to formalize (Webb, 1999) but it may be understood.

Levinas presents his ethics in confrontation to the correspondence which Western philosophy establishes between knowledge (understood as unselfish contemplation), and Being (understood as the locus of the intelligible) (Levinas, 1998; page 67). He repudiates the priority granted in Western philosophical tradition to existential facticity (Peperzak, 1997); the fundamental ontology in which Being is a precondition for any ontology. He criticises in particular how this tradition subordinates the personal relation (the ethical relation), to an impersonal relation (the cognitive relation) (Levinas, 1969; page 45). Levinas denaturalises the ambition of philosophy to attempt at a universal synthesis, a reduction of all that is sensed and experienced to a totality wherein consciousness embraces the world in its totality, leaving nothing outside itself, and thus become an absolute thought (Levinas, 1985; page 69); a reduction of everything to a sameness. Levinas wishes to divert us away from the priority given in Western philosophy to Being and Totality. He wishes to turn our attention instead toward that which is not included in this Totality, that which remains outside it, that is to say infinity (Levinas, 1969, 1990b). Levinas strives, after releasing us from the limits imposed on our understanding by our habits, to dissuade from considering knowledge, the Other or the world in ontological terms. His project is to bring us beyond knowledge and essence, beyond being to the otherwise than being (Levinas, 1990a, 1991b); establishing a world between ontology (Heidegger) and 
phenomenology (Husserl) (Davis, 1996) and presenting a means of considering life as it is lived through an intentional, anthropological experience as opposed to a intellectualised contemplative science (Peperzak, Critchley and Bernasconi, 1996).

Levinas does not conceive of ethics as a matter of distinguishing good from evil in action. Ethics is a matter of heteronomous relation to the other. The ontological tradition, however, reduces the other to the same. Comprehending the Other supposes that one applies to the other one's own analytical or judgmental categories. By so doing, one relates and brings back the other to oneself and, thereby, turns otherness into a same. Approaching the other in ontological terms involves that even when one means to speak of the other, one actually only speaks of oneself, a transition that Levinas calls egology (Levinas, 1990b; page 44) The ontological tradition that reduces the other's otherness to the same as it negates his/her radical otherness. Levinas wishes therefore to substitute a nonallergic relation with alterity (Levinas, 1990b; page 47), one that caters for the other's infinite otherness.

Before the infinitude of human relationships, Levinas suggests adopting an affective, nearly sensual, approach to the other and he grounds his ethics in such an approach. He invites us in highly expressive terms - terms that are extravagant (Peperzak, Critchley and Bernasconi, 1996), hyperbolic (Ricoeur, 1992; Webb, 1999; Nuyen, 2001; Davies, 2004), insistently repetitive (Derrida, 2001) and sacrificial (Chalier, 2004) - to a phenomenological contemplation of the greeting, the face (more particularly the gaze or the smile), the caress or sexuality (Levinas, 1969). He tells us that under special circumstances, ethics can even be found in the happy barking of a stray dog (Levinas, 1963). On the relationship to the face and how it opens on an incapacity to grasp the infinite of the other in its totality, Levinas writes for example:

Le visage se refuse à la possession, à mes pouvoirs. Dans son épiphanie, dans l'expression, le sensible, encore saisisable se mue en résistance totale à la prise. Cette mutation ne se peut que par l'ouverture d'une dimension nouvelle. En effet, la résistance à la prise ne se produit pas comme une résistance insurmontable comme dureté du rocher contre lequel la main se brise, comme éloignement d'une étoile dans l'immensité de l'espace. L'expression que le visage introduit dans le monde ne défie pas la faiblesse de mes pouvoirs, mais mon pouvoir de pouvoir. (Levinas, 1990b; page 215)

The Face resists possession, resists my powers. In its epiphany, in expression, the sensible, still graspable, turns into total resistance to the grasp. This mutation can occur only by the opening of a new dimension. For the resistance to the grasp is not produced as an insurmountable resistance, like the hardness of the rock against which the effort of the hand comes to naught, like the remoteness of a star in the immensity of space. The expression the face introduces into the world does not defy the feebleness of my powers, but my ability for power. (Levinas, 1969; pages 197/8) 
Meeting the other establishes for Levinas a face-to-face encounter that raises an imperious moral urgency. My humanity is grounded in my subjectivity and in my face-to-face proximity with the other. The conditions of this face-to-face are the conditions of my humanity. As Simon Critchley (2004) observes this face-toface relation takes place in speech - "the face is not something I see but something I speak to" (Ibid, page 12); the relation is not a visual perception but a linguistic one. "In speaking, or calling or listening to the other, I am not reflecting upon the other, but I am actively and existentially engaged in a non-subsumptive relation, where I focus on the individual .... I am not contemplating, I am conversing" (Op. cit.) and it is this act itself which is ethical practice for Levinas.

As a human being, the face in front of me summons me, asks for me and begs me (Levinas, 1998; page 96). The face is talking to me and "Thou shall not kill" are not only its first words, they are also its first command. We must hear this command and respond to it; that is our moral challenge. For Levinas the proximal face-to-face raises an imperious moral urgency. My humanity is grounded in my subjectivity and my subjectivity in turn is grounded in my faceto-face with the other. The conditions of this face-to-face are also the conditions of my humanity. Being ethical is being responsible for the other:

pour l'autre, malgré soi, à partir de soi; la peine du travail dans la patience du vieillissement, dans le devoir de donner à l'autre jusqu'au pain de sa bouche et du manteau de ses épaules (Levinas, 1990a; page 93)

for the other, despite oneself, starting with oneself, the pain of labour in the patience of ageing, in the duty to give to the other even the bread out of one's own mouth and the coat from one's shoulders. (Levinas, 1991b; page 55)

The ethics of Emmanuel Levinas is an ethics of responsibility. This responsibility for the other is immediate and not only a matter of perception. As soon as someone looks at me, I am responsible for her. I do not need to take any responsibilities toward her. This responsibility is mine and I can neither ignore nor refuse it. Levinas writes:

[L]'abord du visage n'est pas de l'ordre de la perception pure et simple, de l'intentionalité qui va vers l'adéquation. Positivement, nous dirons que dès lors qu'autrui me regarde, j'en suis responsable, sans même avoir à prendre de responsibilité à son égard; sa responsabilité m'incombe. C'est une responsabilité qui va au delà de ce que je fais. (...) [J]e suis responsable de sa responsabilité même. (Levinas, 1992; page 92)

$[\mathrm{M}]$ eeting the face is not of the order of pure and simple perception, of the intentionality which goes toward adequation. Positively, we will say that since the Other looks at me, I am responsible for him, without even having 
taken on responsibilities on this regard; his responsibility is incumbent on me. (...) I am responsible for his very responsibility (Levinas, 1985; page 96)

My responsibility is thus both without start and endless. It is also non-reciprocal. I neither calculate nor expect reciprocity. I carry my responsibility and reciprocity belongs to the other's responsibility:

[J]e suis responsable d'autrui sans attendre la réciproque, dût-il me coûter la vie. La réciproque, c'est son affaire. C'est précisément dans la mesure où entre autrui et moi la relation n'est pas réciproque, que je suis sujétion à autrui; et je suis 'sujet' essentiellement en ce sens. C'est moi qui supporte tout. (...) [J]e suis responsable d'une responsabilité totale, qui répond de tous les autres et de tout chez les autres, même de leur responsabilité. Le moi a toujours une responsabilité de plus que tous les autres. (Levinas, 1992; pages 94/5)

I am responsible for the Other without waiting for reciprocity, were I to die for it. Reciprocity is his affair. It is precisely insofar as the relation between the Other and me is not reciprocal that I am subjection to the Other; and I am 'subject' essentially in this sense. It is I who support all. (...) I am responsible for a total responsibility, which answers for all the others and for all in the others, even for their responsibility. The I always has one responsibility more than all the others. (Levinas, 1985; pages 98/9)

Doing something for the other and giving: my responsibility is the identification mark of my humanity and spirituality. I am indeed totally subjected to it. It goes actually as far as being responsible for the life of the other before one's own life. On this account Levinas clearly departs from Kant. As Agata Zielinski (2004) points out, whilst close to Kant, Levinas goes much further with the undirected character of moral action. Levinasian responsibility is without why (sans pourquoi). It is neither prompted by the subject herself nor sparked off by a third, but originates instead in the evasive absolute that is the alterity of the other.

The philosophical signification of responsibility is the central theme in the ethics of Emmanuel Levinas and a recurrent motive of broad theoretical elaboration in his writings. His elaboration on the differences between saying and the said (Levinas, 1990a, 1991b) - the former resisting the ontological character of the latter - begins with the issue of how to concretely take one's responsibility toward the other and more generally how to define the conditions of one's encounter with the other. His adding the presence of a third party to the interpersonal relationship one entertains with the other, opens likewise for the issue of justice: the interpersonal relationship that I entertain with the other facing me, I also need to entertain it with other; I have therefore a responsibility 
to moderate the privilege I grant to the other in front of me, hence to answer for justice (Levinas, 1985; page 84).

Levinas' ethics keeps redefining the terms of an unlimited personal responsibility that would start and end beyond ontology and therefore reach, beyond the Being of the other, the existent of the other's radical otherness and thus the infinite humanity of humans beings. It is in this sense that ethics is for Emmanuel Levinas first philosophy.

\section{On the impossibility of a corporate ethics}

What about the possibility of developing a corporate ethics (in the sense of an organisational ethics for for-profit organisations) if one approaches ethics in the footsteps of Emmanuel Levinas? We will argue that there is no such possibility. We contend that if one approaches ethics through the moral philosophy of Emmanuel Levinas, the mere possibility of speaking of a corporate ethics disappears and only the possibility of a personal (qua managerial) ethics remains - moreover on a reduced scale, as Levinasian moral criticism proves to be devastating when applied to managerial activities. We will develop the first part of this reasoning in this section and the second one in the next one.

Asserting that a corporation can be ethical in the sense given to the term by Emmanuel Levinas involves assuming that a corporation can develop ways to open itself as endlessly responsible toward the otherness of the Other. It is not a matter of reducing Levinasian ethics to a variant of instrumental stakeholder management and asking whether a corporation can participate in a dialogue with others. It is instead to ask if a corporation can get itself ready to go into an endless offering of itself for the sake of radical alterity. Can a corporation with limited liability become a hostage of the Other? Our answer to this question is categorically "no".

By legal definition, a corporation is self-centred. It is legally bound by its charter to some place of business, purpose, objectives and goals, some charters even specifying what the corporation can and cannot do while pursuing these goals. A corporation a legal construction (Sison, 2000). We concede that there may be more to corporations than is asserted by some legal fiction purists (Scruton, 1989; Metcalfe, 1998). Corporations are seen as imperial leviathans (Hardt and Negri, 2001; Chandler and Mazlish, 2005), they are increasingly global (Mitchell, 2001; Gabel and Bruner, 2003) and with an encompassing economic power that challenges the supremacy of the State as the ruling institution (Korten, 1995; Hedetoft, 1999; Chomsky, 2004). Neither can we ignore their being multifaceted cultural phenomena (Martin, 2002). Corporations are sophisticated symbolic constructions (Bryman, 2004), as epitomised by 
those who bring the contemporary worshipping of corporate names and logo (Klein, 2001) as far as letting tattooing themselves with Nike's Swoosh, Harley Davidson's name or the Coca-Cola bottle (Bengtsson, Ostberg and Kjeldgaard, 2005). It is strangely enough not strange any longer that Steve Ballmer, chief executive of Microsoft can be applauded for yelling an evangelizing "I Love This Company !" from the stage of a company meeting (See e.g. Gandini, 2003). Corporations are a locus where humans (and non-humans) meet, nothing that is human is foreign to them, including irrationality and affectivity, magic and superstitions and more. They house intensive games of power and submission that make them moral mazes (Jackall, 1988). Ignoring these matters of facts would be inexcusable oversimplification, but equating corporations with persons (or even super-persons) endowed with human qualities is equally contestable.

A corporation remains an abstraction inverted upon its own finality, i.e., the objectives that preside over its existence: offering products and services at a profit for the benefit of its stakeholders among which primarily its stockholders. Serving its self-interest, with profit as a proxy, is the heart of its raison d'etre. Milton Friedman's (1970) frequently quoted assertion is eloquent:

(T)here is one and only one social responsibility of business - to use it resources and engage in activities designed to increase its profits so long as it stays within the rules of the game, which is to say, engages in open and free competition without deception or fraud (Friedman, 2002; page 133).

The assertion of economic theory that the purpose of a for-profit company is to make money for its owners might appear as self-referencing. It nevertheless effectively fixes corporations as institutions that by definition and purpose are subdued to a rationality of ends and means; but organisational life is not always, if at all, rational. When Levinasian ethics enjoins us to approach the other with endless responsibility, love and readiness to sacrifice - corporations evoke plans, procedures, calculations and evaluations. Even more matter-of-fact, when Levinasian ethics enjoins us to give the other priority over oneself, corporations answer only with a primary concern and responsibility to serve their self-interest. On these accounts, Levinasian ethics and corporate logic appear as diametrically at odds one with another.

Levinasian ethics and corporate logic are not at odds one with another only on the account that a corporation is purposeful social system oriented toward itself and the service of its self interest rather than the other. They are even more fundamentally at odds one with another with on the account that a corporation is not a human ${ }^{1}$. A corporation has no body, no face, no voice except in a metaphorical sense. Its materiality in this regard is an anthropomorphic delusion.

${ }^{1}$ For a discussion of this issue from a Kantian perspective, see Stephen Wilmot (2001). 
Corporate artefacts such as buildings, machines, products, signboards, logos, brochures or handbooks endow it with accoutrements of property; but they do not endow it with a body in the sense that the living is endowed with a body that breathes, sweats, shudders and feels pain, thirst, hunger and longing. The materiality of organisational artefacts is a materiality of things, not of life (Faÿ, 2004) Whatever apologists of such management fashions as organisational learning or corporate ethics may imagine, a corporation is bereft of subjectivity. It cannot open itself toward and experience the infinite otherness of the Other; it is bloodless, insensible, incapable of consciousness or intention ${ }^{2}$. There is no phenomenology of the corporation.

The greeting, the voice and the cuddling or sexuality and birth are examples of instances of encounters with the other that are beyond the reach of the corporation. Being unable to open itself without limit nor restraint to the otherness of the Other, the corporation is unable to feel any moral obligation toward this other in a Levinasian sense (regardless of whether it may or not be regarded as a moral subject for a legal version of moral responsibility).

Contemporary discourse on organisations may anthropomorphise or objectify corporations, either to glorify (Temporal and Alder, 1999) or to demonise (Bakan, 2004) them. The corporation remains an abstraction, like the Nation, the right to property or Big Bang theory. Legions of employees or vast capitalisation notwithstanding, anything beyond the legal fiction is the product of imagination.

Corporations are perceived as actors but are nonetheless faceless. They have no intimacy to offer the sentient, who scan the world looking for a face; corporations deflect our subjectivity.

Let us illustrate this with the example of the company where a friend of ours works. The company exists only because of the will and ability of some others to convince us that it exists and their corresponding capacity to organise and translate their view into something that can be registered and called a corporation (in this resides the entrepreneur's talent). We can visit its premises all over the country, read its organisational chart, or skim through the interminable list of its transactions. We can even, under some conditions, assert our rights for a share of the wealth it produces. On some occasions, although most often in a vague way, we will even be able to feel the presence of its specific culture. All this is however a matter of agreement only between the

\footnotetext{
${ }^{2}$ Refusing to accept in a literal sense any metaphorical understanding of corporate corporality, we hereby distance ourselves from John Roberts $(2001,2003)$ on the occasions when the latter, while recognising the corporeal character of Lévinasian ethics, assumes the existing of a corporate body, even a corporate skin, and extends his reasoning on Lévinasian sensibility to corporations to speak of 'corporate sensibility'. We also disagree on the same grounds with Aasland (2004) when he claims that Lévinas' description of ethic as being 'the-one-for-the-other' is not dissimilar to the goal of a corporation of being 'for the customer'.
} 
sentient. The company can at any time be changed in legal status, move to new premises, be headed by new leaders, be given a new name and even change of activity, even cease. Some future government can consider it as illegal or useless and rule it out, its owners can choose to sell or to discontinue it, its patrons might turn their back to it and more.

The company where our friend works does not exist in the same sense that our friend exists. It is vividly a matter of perception for us who are friends together. We can see our friend's face and in proximity hear the sound of his voice, take his arm, meanwhile our reptile brains process the unique scent combining from his living proximity. We sense the presence of our friend with all of our body; a corporeal experience not reducible to a swipe card. Our friend is not a construction of the mind, even if our relationship is. He is alive.

When Emmanuel Levinas establishes ethics as the condition of humanity, he also sets ethics aside exclusively for humans (although, more generally, that which is conscious of the other and alive $e^{3}$. Levinas sets very strict conditions for an encounter with the other to be considered as ethics. So strict indeed that only living beings are likely to fulfil them. This precludes any possibility for a corporation to be an ethical subject. We side with those who suggest an oppositional approach to ethics (Caputo, 1993; Parker, 1998; Jones, Parker and ten Bos, 2005) - although we do not maintain that these authors would agree with our position. We also agree with those who, perceiving today's business ethics as an essentially non-disruptive, calculative and legalistic amoralism, start deconstructing it to question whether a business ethics is at all possible (Jones, 2003). We too critically claim that Levinasian ethics disqualifies altogether even the possibility of imagining a corporate ethics, and that this claim may be of some positive value in understanding the radical (ethical) failure of the business ethics project.

Business ethics has become an industry (Hyatt, 2005) swept along and largely subsumed into our audit society (Power, 1999) and corporate ethics is doing well as a management technique. Seminars, handbooks and articles spread in unison the message that corporations need to do good if they are to do well, promoting the business case for business ethics. Business ethics thrives in the wake of pornographically proportioned scandals in corporate accounting and management: Enron, Arthur Andersen, Parmalat, Skandia or Vivendi. It is de rigeur to denounce the greed of (yesterday's) directors (Monbiot, 2000; Moore, 2004) and to advocate the need for clear and strict rules (Doane, 2002a, b; Sethi, 2003) to rescue markets and capitalism from erring irresponsibility and boundless cupidity, as exemplified by the Sarbanes-Oxley Act in the USA (Congress, 2002), the Operating and Financial Review in the UK (DTI, 2004),

3 This extension to encompass Bobby, the stray dog that reminded the Jewish prisoners of war belonging to the same work-commando than Emmanuel Lévinas that they were still alive and human beings (Lévinas 1963). 
or the Swedish code for corporate governance (Kodgruppen, 2004). The job market for ethics or compliance officers is booming and expected to remain so for a while. But for Levinas anything that becomes thematised cannot be ethical: a code of ethics is thus an oxymoron, a CSR statement a formulaic sequence of qualities reduced to the said. Ethics cannot be reduced in such ways.

One unrelenting question in a Levinasian ethical context, however, is how ethical is corporate ethics? How much of an ethics is it and how much of a technique is it? John Roberts (2001) denounces in it an ethics of narcissus: not a moral concern but a concern for better corporate appearances and selfpresentation. Campbell Jones et al. (Jones, Parker and ten Bos, 2005) argue likewise that current business ethics fails to deliver its promises: they find business ethics seemingly compromised to its very core, resisting to the very things it advances and more generally below the expectations and demands of contemporary moral philosophy. Our claim is that a more radical critique can be formulated toward corporate ethics with the assistance of the moral philosophy of Emmanuel Levinas: There can be no question of a corporate ethics. The rationale behind this statement is that if ethics is first philosophy, humans only can claim ethics and it then becomes impossible to speak of corporate ethics as corporations are non-humans. As a consequence, if one (still) wishes to speak of business ethics, it can only be question of managerial ethics.

\section{Toward a Levinasian managerial ethics}

In as much as we have seen that Levinasian ethics is critically distanced from classic ethical theory, must ${ }^{4}$ we similarly expect that a managerial ethics of Levinasian inspiration need to be critically distanced from classical approaches to managerial ethics based on, for example, virtue ethics, deontology, egoism or utilitarianism. These moral theories being denominated and designated in that which Levinas calls the egology of the ontological tradition, it makes little difference whether one elects some special virtues to cardinal managerial virtue, compiles a set of rules for good conduct, sets up procedures to satisfy one's own interest or designs an algorithm to assess the consequences of corporate action on its stakeholders. Virtues, rules, self-interest or principles are all reductions; reasoned expressions of values, judgmental categories, preferences or modes of understanding that are specific to whoever enounces them. As such, they merely express the ethical penchants of who proclaim them, hardly anything more.

\footnotetext{
${ }^{4}$ Emmanuel Lévinas has in his writings touched upon commerce but hardly on management [see Lévinas (1969; 1990b; page 250 et seq), Burggraeve (1997) and Aasland (2004; 2005)]. We therefore prefer to use here a tense that reminds that the reasoning presented here about a Lévinasian managerial ethics is propositional, nearly hypothetical, rather than assertively normative.
} 
A Levinasian managerial ethics would emerge as a result of otherness. It would delimit relationships with the other as the locus of the ethical and work on unfolding the conditions of a boundless managerial responsibility toward alterity. As introduced above (Section 1: The Ethics of Emmanuel Levinas), Levinasian ethics is an ethics of responsibility. Most important, Levinasian responsibility is not a matter of being regarded as worthy of praise or blame for something that can be causally connected to one's behaviour as knowledgeable and free moral agent (for an expose of this traditional definition. see e.g. Eshleman, 2004). Instead of defining responsibility in terms of an attribution process affixed to a causal connection, Levinas defines responsibility as the providing of a response to the infinite demand and command imposed on me, indeed constitutive of me, by the mere existing of the other and her call for existing; a life in peace, as incarnated in the face that she turns on me. This call always comes first as questions always pre-exist answers which is why my responsibility is engaged before any acting or awareness of mine, indeed before anything else - ethics as first philosophy, again.

So could a Levinasian managerial ethics be instantiated in the character of managerial work. Certainly, a central characteristic of managerial work is to consist in a faire-faire (Hees, 1999), approximately a do-to-get-done. Managers are in and by their organisational functions permanently in contact with others since being a manager consists in acting on others' acting to get special things done. They spend most of their time interacting with others, either individually or in groups, either face to face or in other-mediated ways (see e.g. Tengblad, In press). However, these relations take place under highly specific social conditions that hardly enable them to entrain a Levinasian responsibility. Assymetries of power relation (Jackall, 1988), ad-hoc loyalties (Flamant, 2002), unclear duties (Villette, 1996) as well as suffering (Dejours, 2000) and toxic emotions (Frost, 2003) are part of everyday repertoire of organisational behaviour. An imperative of performance (Ehrenberg, 1991; Le Goff, 1995; Corvellec, 1997) permeates and directs managerial conduct. Managers must assume the status of entrepreneurial subjects within their own existence (du Gay, 2005), but with relatively little freedom to act as they please. Managers' actions and in particular their relationships to others are scripted; determined in form and content by considerations of hierarchies, interests, purposes and outcomes.

Reconciling the requirements of a Levinasian ethics with the working conditions of managers appears difficult in many ways. We may assert a convergence between the relational character of managerial activity and the relational character of Levinasian ethics, but this convergence falters around irreconcilable difficulties. The relations of managers with others are in fact hierarchical, final, instrumentalised, controlled and commodified. Such relations are irreconcilable with, the demand for endless and gratuitous responsibility for the other of Levinasian ethics. Managers are forced into permanently relating to others, but whether they will be able or not to address the Other with the 
selflessness and lack of reserve characteristic of Levinasian ethics remains an open issue.

One could argue that it will never be possible to reconcile managerial activity with Levinasian ethics. Managers approaching the other in an instrumental way, or the recurrent, incessant prevalence of self-interested motives in managerial diurnality, can be used as evidence for a fundamental irreconcilability of management standing as everyday practice with Levinasian ethics standing as normative moral philosophy - lest to betray the core of Levinasian moral philosophy. John Roberts (2001) suggests it is difficult to see how a selfinterested, autonomous, limited liability corporation could contemplate such levels of responsibility Shelby Hunt (2003) does not single out Levinas, but appears to consider that all continental philosophy is a metaphysical pretension which is only a wasteful distraction away from the truth and objectivity required to seriously understand markets. Equally, one could argue that what is needed is a radical social change option. Since capitalism creates inhuman social conditions for labour (see e.g. de Villarme, 1840; Weil, 1951; Linhart, 1978; Dejours, 2000). and these conditions prevent managers from being ethical, then one should replace the social conditions of capitalism and/or modernity with ethics enabling ones (see e.g. Parker, 2002).

We prefer to argue for the invention of a managerial ethics of Levinasian inspiration. Such an ethics would propose to introduce elements of Levinasian ethics into management contexts whenever managerial discourse and practice offer lacunae, breaches or fractures likely to be filled with a radical concern for otherness. It would acknowledge that Levinasian ethics may be the opposite of a moral system and that any attempt to turn it into a practical ethical totality would be contrary to its core tenets. It nonetheless seeks to reorganise managerial ethics so as to let the resounding effect of Levinasian ethics in moral philosophy have its distinctive echo in managerial and organisational contexts. A Levinas inspired managerial ethics is proposed as a way to inform managerial practice with the basic Levinasian claim that ethics is heteronomous. It is not situated in deliberations of the individual as moral subject but in the relationship that this subject, as a being, has with the beings of other moral subjects. It asserts an effort to redirect managerial ethics away from ontologically-based ethical theories and to ground it in radical otherness and the irresistible call to a pre-ontological, timeless and infinite individual ethic. It is both a critical and a propositional endeavour to bring the attention of managers to the fact that humanity resides in the encounter with the otherness of the Other and that preparing oneself to this encounter is everybody's primary responsibility as a human being. 


\section{Otherness and Responsibility}

In line with Levinasian ethics, Levinasian managerial ethics is also a matter of heteronomous relation to the other. It is prompted by the infinite and radical Otherness of the other and involves a responsibility that, among other things, does not reduce otherness to the same. It is also, as detailed above, exclusively an individual responsibility, not a corporate one.

The other calls us, and for a manager taking responsibility points to putting oneself in the position of offering a response to this call, in the various sense of the term offering: from making a proposal to presenting an act of worship through agreeing freely or staging a performance. This response is moreover to be offered here and now. As Zigmunt Bauman (1993) insists, the ethics of Emmanuel Levinas entails the rejection of any idea of universal moral norms. Consequently, a Levinasian moral project can only be local and contingent in the sense of being part of a here and now from which it cannot be disentangled. Alterity expresses itself as it stands in front of me; right here and right now. For Levinas Otherness is not an intellectual abstraction but a here and now reality. It is epitomised in the uniqueness of every face-to face: every 'face' and every 'to' - the standing in front of the other in the face-'to'-face - is unique, in place and time. Acknowledging this unique real character of the encounter is not being relativistic. It is being aware that the occasional is the condition of our encountering and facing alterity.

For a manager, this implies that each response has to be modestly provided in function of the specific traits of the situation at stake. This is not plainly restating the relativism of morality, in particular as opposed to the generality of ethics. It is highlighting instead that responsibility is a matter of refusal and avoidance of that which distance one from the here and now of Otherness. "Beware of all generalisations, classifications, categorisations and definitions" should stand as a motto on the pediment of all companies; or as an aide mémoire on the desk of all managers if they are to avoid the egological contradictions of classic moral theories. Managers need to wary of that which can dis-embed, disembody, rationalise, reduce, typify or generalise alterity. Yet, in undergraduate, or graduate management programmes - in the course of routine exhortations to pragmatic ethical relativism - how frequently does one hear recommendations in favour of a truly contingent and modest approach to the other?

Levinasian responsibility is tenseness and tautness in ceaseless flow; the combination of a relentless will, striving and straining, directed toward the other. Levinasian managerial responsibility involves correspondingly, because one is a manager, being ready to provide a response, always a step ahead of formulated questions, without condition nor restriction and under terms of openness and disinterest. Admittedly this may be something easier to recommend than to implement when one has to take into consideration the organisational constraints of managerial work - hierarchies, interest, purposes and outcomes. It 
is, notwithstanding, something of which managers need to be thoroughly aware at every turn of their acting as manager.

\section{Saying and Said}

The difference that Levinas (1974) makes between the saying and the said can help to set straight how managers can actually enact responsibility. Levinas insists on the difference between the two. For him, the said belongs to ontology: it refers to the verb to be and in it resounds the being of entities, their reasonable essence. The saying, on the contrary, is on the far side of ontology and is emerging timelessly into essence. Taking place prior to the said, to meaning and corresponding reduction, the saying is signifyingness antecedent to any ontology. It is non- reducible to signs and communication and stands instead as an exposure and a proposition to set up a relationship to another. Saying is self-denuding in the sense that one reveals oneself in the saying. It is an effort, an orientation toward openness, proximity and responsibility. In Saying, one approaches the Other in infinity.

Ethical managers should therefore be aware of the difference between the saying and the said. As Paul Ricoeur (1997) asserts, Levinas places the said on the side of ontology and the saying on the side of ethics. This is a radical division that cleaves the correlation established by analytic philosophy of language between the semantics of the enunciated and the pragmatic of enunciation. Saying is not to be reduced to a pre-said or any appendage subordinated to the said. Saying is instead the self-standing commitment of an approach, the one for the other or an utterance of the outside of being. Morality is in the saying, not in the said.

So what of the routine distribution of written mission statements and ethical codes for employees? Levinasian managerial ethics insists less on the content of these texts than on the conditions of their delivery. In turn this would raise, many practical questions for managers, among which: How to speak to your subordinates? How to answer to questions? Do you communicate in written form anything that you could verbalise? Would you be able to read aloud all written texts in circulation in the organisation, and if not why?

Following up on the differentiation between the saying and the said would likewise raise our awareness that written memos are potentially immoral means of distanciation or that anyone using email runs an ethical risk since it is a form of communication that blends the written (said) and the oral (saying) in an unclear manner. Levinasian managerial ethics recommends to prefer management by saying to management by said. It invites managers to exert their ability to provide responses. It also aims at preventing a separation between that which managers say and the circumstances of their saying, so that they say does not get objectified into a said and imposed as such on the other. This is a plea for live face-to-face communication and possibly a radical redefinition of corporate and inter-personal communication. 


\section{Vulnerability}

Communicating in a Levinasian way requires managers to enrich their vocabulary with Levinasian terms and expressions. It takes a particular vocabulary to approach otherness in a Levinasian way. One needs to leave behind linguistic and thinking habits that objectify the Other and deny alterity, even (or especially) those rooted in traditional ethics 5 . Introducing elements of Levinasian terminology into managerial vocabulary is therefore a small but important practical step toward inventing a Levinasian managerial ethics.

Singling out the term vulnerability will illustrate our point more distinctively. Speaking of vulnerability supposes not only that one questions the consequences of one's actions; such an approach would be simply to reformulate classic consequentialism. What vulnerability demands is that one explores in the most cautious way the potential consequences of one's actions for the weakest among all of those who might be affected. Even more than this, it involves taking the place - at least mentally and at least for a while - of the one who receives the hardest hit. New questions come to mind: What if I pledge myself (i.e. my comfort, health, riches and power) for her suffering? What if I turn myself into her hostage? The vocabulary of vulnerability involves abandoning the strong perspective of the strong moral subject and adopting the weaker perspective of the potentially weakest victim. The term vulnerability conceals an injunction: Discard all sorts of reasoning in terms of averaged costs and benefits and imagine yourself instead, at the fullest of yours emotions, in the skin of the worst-off individual in the worst case scenario.

Other terms could serve as similar examples of how Levinasian vocabulary opens on a Levinasian managerial ethics. Radical, alterity and otherness are key terms of this vocabulary that have been repeatedly touched upon here above. Even the face, the gaze, the saying or egology have been discussed at some lengths. Levinasian vocabulary is rich of yet many other terms, e.g. openness and listening, thoughtfulness and respect, guidance and servitude, or weakness and substitution. These are terms that support an understanding that being in relationships with another involves endless moral responsibilities toward this other, in particular toward that which makes this other just an other. This is why Levinasian vocabulary makes it possible for managers to clarify the ethical dimension of their relationship with otherness, in its daily and concrete manifestations as well as in its most abstract theoretical elaborations.

Introducing Levinasian terms into managerial vocabulary is a contribution to developing the disposition and ability of managers in the practice of encountering alterity. It is an initiative which emphasises the critical workplace

\footnotetext{
${ }^{5}$ On this account, we acknowledge McPhail's (2001) aspiration to reform accounting education and the accounting profession in the direction of a greater sense of moral sympathy for the other.
} 
diversity management concerns (See e.g. Prasad, Mills, Elmes and Prasad, 1997), which have yet to transcend themselves in the direction of acknowledging radical otherness. Levinasian ethics proposes a vocabulary that makes it feasible to develop one's sensitivity to and awareness of otherness. The Levinasian vocabulary can therefore prove to be invaluable to managers wishing to exert a Levinasian responsibility.

\section{Proximity}

As indicated by the importance that Levinasian ethics disposes to the face-to-face, the gaze or other forms of affective or sensual approaches to the other, it is an ethics of proximity ${ }^{6}$. However, proximity should not be understood in the sense of spatial contiguity (cf. Euclidian geometry). Neither should it be resolved into the consciousness that a being would have of another being that it would judge to be near inasmuch as the other would be in his sight or within one's physical reach, for example for conversation, commerce or the exchange of handshakes. Proximity is instead a comprehensive enactment of an obsession for the other and human wholeness. Levinas declares emphatically that the absolute and proper meaning of proximity presupposes "humanity" (1974/1981, page 81). Proximity emerges from an obsession to get closer and closer. It is the condition of signification and an incontrovertible condition of the exercise of Levinasian ethics. This is true in particular for the exercise of responsibility: "Proximity, difference which is non-indifference, is responsibility." (Levinas 1974/1981, page139). To put it concisely: proximity is the saying of responsibility.

If proximity is a matter of saying, Levinasian vocabulary may be a way of working toward proximity. Equally important for our topic, when Levinas (1974) elaborates on proximity being a condition for responsibility, he simultaneously warns us against the risks involved by distance. This is a highly relevant warning for managers or management and organisation theory scholars as a key characteristic of management as acting at a distance (Robson, 1992), a feature of management reinforced by globalization (Collier, 2000; Royle, 2005) . Levinasian ethics delivers a crucial message when it reiterates that otherness cannot be experienced at a distance. This message is that distance - literal or metaphorical - impedes one's approach to alterity; it favours instead egological practices and should therefore be handled with care.

Management implies remoteness and to put it bluntly managers are to be considered as potentially dangerous. From a Levinasian perspective, techniques that render the other faceless and speechless, are unethical and unfair (Introna

\footnotetext{
${ }^{6}$ Instead of proximity, one could speak of closeness to express that it is more than merely a matter of physical distance or even propinquity to capture the idea that it is a combined nearness of purpose, blood, place and time. Proximity is however conform with Alphonso Linguis' translation of Autrement qu'être (1974/1981).
} 
2003). So then, let managers mistrust techniques that alienate or abduct their words, decisions and actions. These techniques dangerously neutralise the faceto-face as they seek to increase their remoteness from other beings. There are numerous examples of such techniques from standard performance evaluation procedures to strategic resource allocations schemes through accounting techniques such as budget or costing that objectifies the other when turning the corporation into an object for computations (see e.g. Merino, 1998; Dillard and Ruchala, 2005) Levinasian ethics warns us all that such techniques, as all techniques that enable acting at a distance, are potentially anonymising, degrading and thereby deprived of humanity.

If the gaze is an uncompromising reminder of the injunction that "Thy shall not kill", one should be careful whenever one leaves its realm. Levinasian ethics advises us of the threat present in all forms and means of remoteness when it comes to take one's responsibility to promote and defend proximity with the other. A Levinasian vocabulary is a compelling reminder of it.

\section{Diachrony}

Some might consider time as a form of remoteness. For Levinas, however, time flows ceaselessly (rather as in the words ascribed to Pythagoras by Ovid (2004; Book XV, lines 176-198)) and notions of chronology are a mere reduction. John Llewellyn suggests that for Levinas "every moment of the recollectable time of my going forward to my own death is cut through [dia] by the interlocution of other mortal beings" (Llewellyn, 2002, page 136). In the temporal flux, our face-to-face encounters with the other result in a cut across time - a diachrony. Diachrony presents itself as time and awakening for Catherine Chalier (2004) "and is experienced as a relationship to the irreducible mystery of the otherness of the neighbour; a diachrony which keeps pace with what remains other and which, in the face-to-face with the other calls me and asks for me; time as vigilance and patience, time as awakening and disturbance" (Ibid, page 114).

Managers, however, tend to live by synchrony even when their actions unfold through time. Numerous managerial technique - e.g., enterprise resource planning (ERP), just-in-time (JIT) or critical chain project management (CCPM) - aim at structuring time for control purposes; the control of time being a recurrent concern in globalised modernity (Beck, 1999; Nandhakumar and Jones, 2001). Time is approached as resource the use of which should be optimised. Managers expend great efforts to make time a manageable variable. They cut time into tradable units and trade it as any other commodity. A unit of time at $\mathrm{t} 1$ is given a time or monetary equivalent at $\mathrm{t} 2$ or another equivalent at $\mathrm{t} 3$. The time of managers is rationalised and reified. Management objectification of time can be viewed as an effort to turn time into a flat synchronic resource placed in the hegemonic service of global capital. 
It might therefore be apposite to consider the observation made by Simon Critchley that these "two orders of discourse the Saying and the Said, do not occur in the same time. They are "non-simultaneous" and "incompressible" (Critchley, 1999, page 165). In such rationalisations we move between the temporal orders; diachrony is reduced to synchrony. "In short, synchrony reduces time to space. It is a conception of time that lets the past be recalled and the future predicted. Diachrony, on the other hand, refers etymologically to the coming apart of time, the inability to recall the succession of instants within memory or to predict the instants to come. Diachrony is an immemorial, dispersed temporality which escapes and passes by" (Op. Cit.). In the Saying, the manager relates in a face to face diachronous relation with the otherness of the Other in proximity; in the Said, the manager is abducted, reduced and distanced from the Other in the sameness of synchrony. Ethical managers need to communicate live, diachronologically, with those who call out for them.

\section{The Third and Justice}

When emphasising that proximity should not be understood in the reduced sense of spatial contiguity, Levinas signals his awareness that there exists, beyond the realm of my gaze, another other than the one in front of me and to whom I am all the same responsible. Levinas calls this other for the third (le tiers). The third is the other of the other who stands in front of me. With the discovery of the third, I am reminded that the other is never simply my other, and that there exists an infinity of others. I owe everything to the other, but there is something else: a necessity to moderate the privilege that I grant the other (Levinas, 1992; page 84).

Colin Davis (1996) claims that the third prevents my relationship with the other from becoming too cosily self-enclosed; the third disturbs the intimacy of my relationship with the other and provokes me to question my place in the world and my responsibility toward society. My relationship toward the other is, albeit endless and non-reciprocal, now re-doubled by my being an other for the third. For William Simmons (1999), this involves an extension of the ego's responsibility. The ego cannot prioritize those in proximity and must give attention to all. It is not possible to respond infinitely to all others. Whilst the ego remains infinitely, asymmetrically and concretely responsible for the other, it must also weigh its obligations toward the third. This weighting can be done, according to Simmons, by ascribing, on the one hand, the relationship to the other to the saying and ethics and, on the other hand, the relation to the third to justice and the said. The third opens for the realm of politics with justice as its core.

Considering management as a form of politics conducted at the scale of the organisation, one could transfer the reasoning above into the realm of management. The third emphasises that, along with an endless responsibility 
toward the proximate other, a manager's responsibility extends even to other others. Justice for the third links proximity with the neighbour in a community of others, in which each is responsible for all. Through justice, the principles of proximity, openness and responsibility to the third party are extended to all. I am not only near, open to and responsible for the other who is facing me. The same is true for all others. This is more than stakeholder management (Freeman and Reed, 1983); it is more like an actualisation of the Rights of Man and, as Levinas (1991a) describes it, the promotion of goodness and responsibility for the other as means of eradicating completely the ultimate harshness of the Inhuman in being. Assuming an endless responsibility for goodness to serve justice, such is the agenda set to man by Levinasian ethics. We find no reason to change anything to such an agenda when speaking of managers except that, may be, instead of referring to French Rights of Man from 1789 as Levinas does, one could refer instead, with Bert van de Ven (2005), to more actual and global Universal Declaration of Human rights by the United Nations. Managers face a clear summons: Think, whenever possible, in terms of human rights and justice for all.

Clive Barnett (2005) claims that the contribution of Emmanuel Levinas to geography is to ask the questions of how far moral obligations actually extend and how to reconcile an ethics of care with an ethics of justice. The same could be said of Levinas' contribution to management studies. A managerial ethics of Levinasian inspiration is an invite to practically conciliate concerns of care for the proximate other with concerns of justice for all. Answering the invitation is the managers' first responsibility and, conversely, not answering this call is unethical.

\section{Summary and concluding remarks}

Levinasian ethics is a "Humanism of the Other" (Levinas, 1972). It is an ethics of endless responsibility for the other and for justice. Our first claim is that such a responsibility cannot be contemplated by a limited liability corporation. Corporations lack the bodily subjectivity that is the precondition of a Levinasian approach to the Other; only humans can act ethically and since corporations are not humans, it is impossible to speak of corporate ethics, we can only speak of managerial ethics. Our second claim is that management - being a faire-faire (Hees, 1999), a mechanically isomorphic regime (Maley, 2004) re-acting to the actions of another - abnegates all such responsibility. Management is only interested in the other in order to make it the same; it engulfs, assumes and incorporates the other in this process. Alterity is however perceivable in the most intimate actions of managers, which is why we insist that Levinasian ethics is topical for managers.

The agenda set by Levinasian ethics is a demanding one. It entails being aware of the other, making her part of one's intentionality and exposing oneself 
to her alterity. It also entails answering to her demand, which is a command, of her face and her gaze in proximity and providing an answer to all, at every moment, limitless and unrestricted, a step ahead of any question. The challenge facing a Levinasian managerial ethics is to find ways to integrate such an agenda into the social and professional reality of managers.

Refering to Levinasian concepts such as otherness and responsibility, saying and said, vulnerability, proximity, the third and justice, we present a series of questions and injunctions aimed at orienting a managerial ethics of Levinasian inspiration. These words and injunctions are intensely consequential, for example when we appeal to you to avoid generalisation or to conduct relations with a sense of personal justice. Others are more diffuse, for example when we recommend managers to increase their exposure to the other. We accept that there are the limits to a description of a Levinasian ethics for managers. Levinasian ethics is resilient to systematisation and reducing it to a set of instructions - a suggested code of ethics for managers - would be a contradiction in own terms. However, in the way that Levinas's Said, albeit paradoxically, may assist us (all) in grasping the seriousness of the Saying; we suggest that the questions and injunctions here Said can take managers closer to a point at the limits of totality from which infinity is perceivable. We strongly commend this unreasonable ethics as a means to ethical management; but we cannot reduce them to a code of practice because that would be counter-Levinasian

As managers already live under numerous social constraints among which hierarchies, interest, purposes and outcomes; all a Levinasian managerial ethics adds to this list is an infinite responsibility for the Other. We do not make this suggestion because some economic theory supports it; in the context of managerial responsibility economists generally seek to reduce rather than magnify stakeholder constituencies. Neither is our exhortation based in a business case: Rather because managers are human beings - we all interact with each other and There Is No Alternative, no otherwise, than being. We advocate re-focussing on the human, if institutionalised capitalism is not to be regarded, at some future moment, as an archetype of barbarity. 


\section{References}

Aasland, D. G. (2004) On the ethics behind "Business Ethics". .Journal of Business Ethics, 53, 1 3-8.

Aasland, D. G. (2005) Towards a re-interpretation of business: a Levinasian approach to ethics in business. In Levinas, Business, Ethics, Centre for Philosophy and Political Economy, The University of Leicester, Leicester.

Bakan, J. (2004) The Corporation: The Pathological Pursuit of Profit and Power. Free Press, New York.

Barnett, C. (2005) Ways of relating: Hospitality and the acknowledgement of Otherness. Progress in Human Geography, 29, 1 5-21.

Bauman, Z. (1993) Postmodern Ethics. Blackwell, Oxford.

Beck, U. (1999) What is Globalization? Polity Press, Cambridge.

Bengtsson, A., Ostberg, J. \& Kjeldgaard, D. (2005) Prisoners in paradise: Subcultural resistance to the marketising of tattooing. Consumption Markets and Culture, 8, 3 261-274.

Bryman, A. (2004) The Disneyization of Society. Sage, London.

Burggraeve, R. (1997) Emmanuel Levinas et la Socialité de l'Argent. Peeters, Leuven.

Caputo, J. D. (1993) Against Ethics: Contributions to a Poetics of Obligation with Constant Reference to Deconstruction. Indiana University Press, Bloomington IN.

Chalier, C. (2004) Levinas and the Talmud. In The Cambridge Companion to Levinas, (Ed., Critchley, S. and Bernasconi, R.) Cambridge University Press, Cambridge pp. 100-118.

Chandler, A. D. \& Mazlish, B. (Eds.) (2005) Leviathans - Multinational Corporations and the New Global History. Cambridge University Press, Cambridge.

Chomsky, N. (2004) Hegemony or Survival: America's Quest for Global Dominance. Penguin Books, Harlow.

Collier, J. (2000) Editorial: Globalization and ethical global business. Business Ethics: A European Review, 9, 2 71-75.

Congress, U. (2002) Sarbanes-Oxley Act of 2002. January 23, Washington (DC)

Corvellec, H. (1997) Stories of Achievements - Narrative Features of Organizational Performance. Transaction Publishers, New Brunswick NJ.

Critchley, S. (1999) The Ethics of Deconstruction: Derrida and Levinas. Edinburgh University Press, Edinburgh.

Critchley, S. (2004) Introduction. In The Cambridge Companion to Levinas, (Ed., Critchley, S. and Bernasconi, R.) Cambridge University Press, Cambridge, pp. $1-32$. 
Davies, P. (2004) Sincerity and the end of theodicy: three remarks. In The Cambridge Companion to Levinas, (Ed., Critchley, S. and Bernasconi, R.) Cambridge University Press, Cambridge, pp. 161-187.

Davis, C. (1996) Levinas: An Introduction. Polity, Cambridge.

de Villermé, L.-R. (1840) Tableau de l'état physique et moral des ouvriers employés dans les manufactures de coton, de laine et de soie. In Bibliothèque Nationale Cat. gen., Paris

Dejours, C. (2000) Souffrance en France - La banalisation de l'injustice sociale. Seuil, Paris.

Derrida, J. (1997) Adieu à Emmanuel Levinas. Galilé, Paris.

Derrida, J. (2001) Violence and metaphysics : An essay on the thought of Emmanuel Levinas. In Writing and Difference, (Ed., Derrida, J.) Routledge, London, pp. 480.

Dillard, J. F. \& Ruchala, L. (2005) The rules are no game: From instrumental rationality to administrative evil. Accounting Auditing and Accountability Journal, 18,5 608-630.

Doane, D. (2002a) Market Failure: the case for mandatory soical and environmental reporting. In New Economics Foundation, London

Doane, D. (2002b) Why the CORE Bill is Good for Business. In New Economics Foundation, London

DTI (2004) Draft Regulations on the Operating and Financial Review and Directors' Report: A Consultative Document. In Department of Trade and Industry, London

du Gay, P. (2005) The conduct of management and the management of conduct: contemporary managerial discourse and the constitution of the 'competent' manager. In Strategic Human Resource Management - Theory and Practice, (Ed., Salaman, G., Storey, J. and Billsberry, J.) Sage Publications Limited, London, pp. 360 .

Ehrenberg, A. (1991) Le culte de la performance. Calman-Levy, Paris.

Eshleman, A. (2004) Moral Responsibility. In The Stanford Encyclopedia of Philosophy, (Ed., Zalta, E.) http://plato.stanford.edu/archives/fall2004/entries/moralresponsibility, Stanford CA.

Faÿ, E. (2004) Personal communication to Herve Corvellec.

Flamant, N. (2002) Une anthropologie des managers. Presses Universitaires de France Paris.

Freeman, R. E. \& Reed, D. (1983) Stockholders and Stakeholders: A New Perspective on Corporate Governance. In Corporate Governance: A Definitive Exploration of Issues, (Ed., Huizinga, C.) UCLA Extension Press, Los Angeles.

Friedman, M. (1970) The Social Responsibility of Business is to Increase its Profits. The New York Times Magazine, 33, 122-126.

Friedman, M. (2002) Capitalism and Freedom. The University of Chicago Press, London and Chicago. 
Frost, P. J. (2003) Toxic Emotions at Work - How Compasionate Managers Handle Pain and Conflicts. Harvard Business School, Boston MA.

Gabel, M. \& Bruner, H. (2003) Global, Inc.: An atlas of the multinational corporation [A visual exploration of the history, scale, scope, and impacts of multinational corporations]. New Press, New York NY.

Gandini, E. (2003) Surplus [TV-program]. In Produced by Atmo for SVT 2003 with the support of Swedish Film Institute and Nordic Film and TV-Fond, Stockholm

Hardt, M. \& Negri, A. (2001) Empire. Harvard University Press, London.

Hedetoft, U. (1999) The Nation State Meets the World: National Identities in the Context of Transnationality and Cultural Globalization. European Journal of Social Theory, 2, 1 71-94.

Hees, M. (1999) De dieux, des héros et des managers. Labor, Bruxelles.

Hunt, S. D. (2003) Controversy in Marketing Theory: For Reason, Realism, Truth and Objectivity. M. E. Sharpe Inc., Armonk NY.

Hyatt, J. C. (2005). Birth of the Ethics Industry"; http://www.business-ethics.com (Read August 17, 2005).

Jackall, R. J. (1988) Moral Mazes - The World of Corporate Managers. Oxford University Press, Oxford.

Jones, C. (2003) As if business ethics were possible "within such limits"..... Organization, 10, 2 223-248.

Jones, C., Parker, M. \& ten Bos, R. (2005) For Business Ethics. Routledge, London.

Klein, N. (2001) No Logo: no space, no choice, no jobs. Flamingo, London.

Kodgruppen (2004) Svensk kod för bolagsstyrning: betänkande. In Fritzes offentliga publikationer, Stockholm.

Korten, D. C. (1995) When corporations rule the world. Earthscan, London.

Le Goff, J.-P. (1995) Le mythe de l'entreprise - Critique de l'idéologie managériale. La Découverte, Paris

Levinas, E. (1963) Polémiques: Nom d'un chien ou le droit naturel. In Difficile liberté. Essais sur le judaïsme, (Ed., Levinas, E.) Albin Michel, Paris, pp. 201-202.

Levinas, E. (1969) Totality and infinity - and essay on exteriority. Duquesne University Press, Pittsburgh PA.

Levinas, E. (1972) Humanisme de l'autre homme. Fata Morgana, Paris.

Levinas, E. (1985) Ethics and Infinity - Conversations with Philippe Nemo. Duquesne University Press, Pittsburgh PA.

Levinas, E. (1990a) Autrement qu'être ou au-delà de l'essence. Le Livre de Poche, Paris.

Levinas, E. (1990b) Totalité et infini -- Essai sur l'exteriorité. Le livre de Poche, Paris.

Levinas, E. (1991a) Droits de l'homme et bonne volonté. In Entre nous. Essais sur le penser-à-l'autre. Paris: Grasset. In Entre nous. Essais sur le penser-à-l'autre, (Ed., Levinas, E.) Grasset, Paris, pp. 215-219. 
Levinas, E. (1991b) Otherwise than Being - or Beyond Essence. Duquesne University Press, Pittsburgh.

Levinas, E. (1992) Ethique et infini - dialogue avec Philippe Nemo. Le Livre de Poche, Paris.

Levinas, E. (1998) Ethique comme philosophie première. Payot \& Rivages, Paris.

Linhart, R. (1978) L'établi. Minuit, Paris.

Llewellyn, J. (2002) Levinas and language. In The Cambridge Companion to Levinas, (Ed., Critchley, S. and Bernasconi, R.) Cambridge University Press, Cambridge, pp. 119-138.

Lyotard, J.-F. (1986) Levinas' Logic. In Face to Face with Levinas, (Ed., Cohen, R.) State University of New York, Albany NY.

Maley, T. (2004) Max Weber and the Iron Cage of Technology. Bulletin of Science Technology Society, 24, 1 69-86.

Martin, J. (2002) Organizational culture: Mapping the terrain. Sage Publications, London.

Merino, B. D. (1998) Critical theory and accounting history Critical Perspectives on Accounting, 9, 603-616.

Metcalfe, C. E. (1998) The Stakeholder Corporation. Business Ethics: A European Review 7, 1 30-36.

Mitchell, L. E. (2001) Corporate Irresponsibility: America's Newest Export. Yale University Press, London.

Monbiot, G. (2000) Captive State. Pan, London.

Moore, M. (2004) The Official Fahrenheit 9-11 Reader. Penguin Books, London.

Nandhakumar, J. \& Jones, M. (2001) Accounting for time: managing time in projectbased teamworking. Accounting, Organizations and Society, 16, 3 193-214.

Nuyen, A. T. (2001) "The "ethical anthropic principle" and the religious ethics of Levinas". Journal of Religious Ethics, 29, 3, 427-442.

Ovid (2004) Metamorphoses. Penguin Books Limited, London.

Parker, M. (Ed.) (1998) Ethics and Organizations. Sage, London.

Parker, M. (2002) Against Management. Polity, Cambridge.

Peperzak, A. T. (1997) Beyond: The Philosophy of Emmanuel Levinas. Northwestern University Press, Chicago IL.

Peperzak, A. T., Critchley, S. \& Bernasconi, R. (Eds.) (1996) Emmanuel Levinas: Basic Philosophical Writings. Indiana University Press, Bloomington IN.

Power, M. (1999) The Audit Society: Rituals of Verification. Oxford University Press, Oxford.

Prasad, P., Mills, A., Elmes, M. \& Prasad, A. (Eds.) (1997) Managing the Organizational Melting Pot: Dilemmas of Workplace Diversity. Sage Publucations, London. 
Ricoeur, P. (1992) Oneself as another. University of Chicago Press, Chicago.

Ricoeur, P. (1997) Autrement - Lecture d' 'Autrement qu'être ou au-delà de l'essence' d'Emmanuel Levinas. In Collection Les essais du collège international de philosophie., (Ed.) Presses Universitaires de France, Paris.

Roberts, J. (2001) Corporate Governance and the Ethics of Narcissus. Business Ethics Quarterly, 11, 1 109-127.

Robson, K. (1992) Accounting Numbers as "Inscription": Action at a Distance and the Development of Accounting. Accounting, Organizations and Society, 17, 7 685709.

Royle, T. (2005) Realism or idealism? Corporate social responsibility and the employee stakeholder in the global fast-food industry. Business Ethics: A European Review, 14, 1 42-55.

Scruton, R. (1989) Corporate Persons. In Proceedings of the Aristotelian Society, The Aristotelian Society, Swansea

Sethi, S. P. (2003) Setting Global Standards: Guidelines for Creating Codes of Conduct in Multinational Companies. John Wiley \& Sons Inc, London.

Simmons, W. P. (1999) The Third - Lévinas' Theoretical Move From An-archical Ethics to the Realm of Justice and Politics. Philosophy \& Social Criticism, 25, 6 83104.

Sison, A. J. G. (2000) Integrated risk management and global business ethics. Business Ethics: A European Review, 9, 4 288-295.

Temporal, P. \& Alder, H. (1999) Corporate Charisma: How to Achieve World-class Recognition by Maximising Your Company's Image, Brands and Culture. Piatkus Books, London.

Tengblad, S. (In press) Is There a 'new managerial work'? a Comparison with Henry Mintzberg's Classic Study 30 Years Later. Journal of Management Studies.

van de Ven, B. (2005) Human Rights as a Normative Basis for Stakeholder Legitimacy. Corporate Governance, 5, 2 48-59.

Villette, M. (1996) Le manager jetable - Récits du 'management réel'. La Découverte Paris.

Webb, S. H. (1999) The rhetoric of ethics as excess: a Christian theological response. Modern Theology, 15, 1 1-16.

Weil, S. (1951) La condition ouvrière. Gallimard, Paris.

Wilmot, S. (2001) Corporate Moral Responsibility: What Can We Infer from Our Understanding of Organisations? Journal of Business Ethics, 30, 2 161-169.

Zielinski, A. (2004) Levinas - La responsabilité est sans pourquoi? Presses Universitaires de France, Paris. 